\title{
Pengaruh Pemberian Atonik Terhadap Pertumbuhan Stek Akar \\ Peluntan (Artocarpus sericicarpus)
}

\author{
Kamaludin \\ Fakultas pertanian Universitas Kapuas Sintang \\ Email: kamaludinkamal27@yahoo.co.id
}

\begin{abstract}
Abstrak: Penelitian ini bertujuan untuk mengetahui pengaruh pemberian Atonik terhadap pertumbuhan dan dosis yang terbaik dalam mempengaruhi pertumbuhan stek akar Peluntan di persemaian. Hasil penelitian ini di harapkan dapat memberikan ilmu dan pengetahuan terutama mengenai pengaruh pemberian Atonik terhadap pertumbuhan stek akar Peluntan dan dapat dijadikan sebagai acuan dalam upaya pembibitan di persemaian. Metode yang digunakan dalam penelitian ini metode eksperimen lapangan alam bentuk faktor tunggal dengan pola dasar Rancangan Acak Lengkap (RAL). Penelitian dengan pola Rancangan Acak Lengkap (RAL) ini terdiri dari satu faktor dan 4 (empat) level perlakuan yaitu A0 (Tanpa Atonik), A1 (Dosis 0,25 ml Atonik per litter air per 9 stek akar), A2 (Dosis 0,50 ml Atonik per litter air per 9 stek akar0, dan A3 (Dosis $0,75 \mathrm{ml}$ Atonik per litter air per 9 stek akar). Setiap level perlakuan diulang 4 empat) kali dan setiap ulangan terdapat 9 stek akar. Hasil penelitian menunjukkan Pemberian Atonik memberikan pengaruh yang sangat signifikan terhadap pertumbuhan jumlah daun, tinggi tunas, jumlah akar dan panjang akar stek akar Peluntan di persemaian, tetapi tidak berpengaruh terhadap pertumbuhan jumlah tunas. Perlakuan pemberian Atonik dengan dosis 0,5 ml per litter air (A2) menunjukkan hasil yang terbaik untuk meningkatkan pertumbuhan jumlah daun, tinggi tunas, dan panjang akar stek akar Peluntan di persemaian, sedangkan untuk meningkatkan jumlah akar yang terbaik adalah perlakuan $0,75 \mathrm{ml}$ per litter air (A3).
\end{abstract}

Kata Kunci : Akar Peluntan, Stek, Atonik dan Pertumbuhan

\section{PENDAHULUAN}

Pemanfaatan buah-buahan

hutan alami yang tidak diikuti upaya pembudidayaan, berubahnya fungsi kawasan hutan maupun alih fungsi kawasan hutan adalah ancaman terbesar akan kelestarian hasil hutan bukan kayu. Salah satu hasil hutan bukan kayu yang terancam kelestariaannya adalah jenis buahbuahan hutan alami dari pohon
Peluntan. Untuk melestarikan keberadaan pohon Peluntan yang multiguna maka perlu dilakukan upaya budidaya, salah satunya dengan perbanyak vegetatif berupa stek akar. Untuk meningkatkan performa pertumbuhan bibit asal stek akar, maka diperlukan zat pengatur tumbuh yang salah satunya adalah jenis Atonik. Atonik merupakan zat berbentuk cair berwarna cokelat yang 
mudah larut dalam air. Bahan aktifnya adalah Natrium

Orthonitrofenol $\quad 0,2 \%, \quad$ Natrium Paranitrofenol $0,3 \%$, Natrium 2,4 Dinitrofenol 0,005\% dan Natrium 5 Nitroguaikol 0,1\%.

Najiyati (1990) menganjurkan bahwa untuk menggunakan bibit vegetatif sebaiknya bibit sambung dan bibit stek. Bibit tersebut karena memiliki kelebihan cepat berbuah, terutama bibit stek, mempunyai sifat sama dengan induknya sehingga dapat dipilih dari induk yang bersifat unggul. Atonik adalah salah satu contoh zat perangsang tumbuh (ZPT) yang berbentuk tepung. Cara pemakaiannya yaitu dengan membasahi lebih dahulu pangkal stek dengan air kurang lebih $2 \mathrm{~cm}$, lalu dicelupkan kedalam ZPT. Cara lain adalah dicampur dengan air hingga berbentuk pasta, pangkal stek lalu ditancapkan ke dalam pasta tersebut (Muljana, 1997:56). Penelitian penggunaan atonik terhadap pertumbuhan stek akar Peluntan di persemaian, khususnya di Kabupaten Sanggau jarang sekali dilakukan bahkan mungkin belum pernah dilakukan. Oleh karena itu, mengingat arti penting dari salah satu komoditi ini serta sebagai upaya menjamin kelestarian jenis pohon Peluntan, maka penelitian mengenai penggunaan atonik untuk memacu pertumbuhan dan hasil stek akar Peluntan sangat diperlukan.

\section{METODOLOGI PENELITIAN}

Penelitian ini menggunakan metode eksperimen lapangan dalam bentuk faktor tunggal dengan pola dasar Rancangan Acak Lengkap (RAL). Rancangan ini digunakan dengan pertimbangan bahwa kondisi penelitian dan bahan yang digunakan relatif seragam (homogen). Penelitian dengan pola Rancangan Acak Lengkap (RAL) ini terdiri dari satu faktor dan 4 (empat) level perlakuan. Setiap level perlakuan diulang 4 (empat) kali dan setiap ulangan terdapat 9 stek akar. Level perlakuan yang dimaksud adalah sebagai berikut:

$\mathrm{A} 0=$ Tanpa Atonik

$\mathrm{A} 1=$ Dosis 0,25 ml Atonik per litter air per 9 stek akar

$\mathrm{A} 2=$ Dosis $0,50 \mathrm{ml}$ Atonik per litter air per 9 stek akar

$\mathrm{A} 3=$ Dosis $0,75 \mathrm{ml}$ Atonik per litter air per 9 stek akar 
Jumlah populasi dalam setiap level perlakuan adalah 9 stek, sehingga populasi seluruhnya adalah $4 \times 4 \times 9=144$ stek. Sampel yang diambil adalah 6 stek setiap level perlakuan, sehingga jumlah sampelnya adalah $4 \times 4 \times 6=96$ stek.

\section{HASIL DAN PEMBAHASAN}

\section{Hasil Penelitian}

Persentase hidup dihitung berdasarkan jumlah stek akar Peluntan yang hidup, yaitu dengan cara membagi stek akar yang hidup dengan jumlah total stek yang ditanam dikalikan seratus persen. Data hasil penelitian mengenai persentase hidup dari setiap perlakuan dapat dilihat pada tabel berikut ini.

Tabel. 1. Persentase hidup Stek Akar Peluntan Sampai Akhir Penelitian

\begin{tabular}{|c|c|c|c|}
\hline Perlakuan & Total Stek & $\begin{array}{c}\text { Jumlah Stek } \\
\text { Yang Hidup }\end{array}$ & Persentase (\%) \\
\hline A0 & 36 stek & 8 & 22,22 \\
\hline A1 & 36 stek & 24 & 66,67 \\
\hline A2 & 36 stek & 24 & 66,67 \\
\hline A3 & 36 stek & 24 & 66,67 \\
\hline
\end{tabular}

Sumber : Analisis Data

Keterangan :

A0 $=$ Tanpa Atonik

$\mathrm{A} 1=$ Dosis 0,25 $\mathrm{ml}$ Atonik per litter air per 9 stek akar

$\mathrm{A} 2=$ Dosis $0,50 \mathrm{ml}$ Atonik per litter air per 9 stek akar

$\mathrm{A} 3=$ Dosis 0,75 $\mathrm{ml}$ Atonik per litter air per 9 stek akar

Tabel 2. Analisis Sidik Ragam Pengaruh Pemberian Atonik Terhadap Pertumbuhan Daun Stek Akar Peluntan di Persemaian.

\begin{tabular}{|l|c|c|c|c|c|c|}
\hline $\begin{array}{c}\text { Sumber } \\
\text { Keragaman }\end{array}$ & $\begin{array}{c}\text { Derajat } \\
\text { Bebas }\end{array}$ & $\begin{array}{c}\text { Jumlah } \\
\text { Kuadrat }\end{array}$ & $\begin{array}{c}\text { Kwadrat } \\
\text { Tengah }\end{array}$ & F. hitung & \multicolumn{2}{|c|}{ F tabel } \\
\cline { 1 - 1 } Perlakuan & 3 & 24,19 & 8,06 & $6,56^{* *}$ & 3,49 & 5,95 \\
Galat & 12 & 14,75 & 1,23 & & & \\
\hline Total & 15 & 38,94 & & & \\
\hline \multicolumn{7}{|c|}{$\mathrm{KK}=6,82 \%$} \\
\hline
\end{tabular}

Sumber : Analisis Data Penelitian,

Keterangan :

** : Berbeda Sangat Signifikan 
Pengaruh Pemberian Atonik Terhadap Pertumbuhan Stek Akar Peluntan (Artocarpus sericicarpus)

Tabel 3. Uji Beda Nyata Terkecil Pengaruh Pemberian Atonik Terhadap Pertumbuhan Jumlah Daun Stek Akar Peluntan Di Persemaian

\begin{tabular}{|c|c|c|c|c|c|}
\hline \multirow{2}{*}{ Perlakuan } & \multirow{2}{*}{ Rerata } & \multicolumn{4}{|c|}{ Beda } \\
\hline & & A0 & A1 & $\mathrm{A} 2$ & A3 \\
\hline A0 & 2,50 & - & & & \\
\hline A1 & 3,25 & $0,75^{\mathrm{ns}}$ & - & & \\
\hline $\mathrm{A} 2$ & 5,00 & $2,50 * *$ & $1,75^{*}$ & - & \\
\hline A3 & 5,50 & $3,00 * *$ & $2,25^{*}$ & $0,50^{\mathrm{ns}}$ & - \\
\hline
\end{tabular}

Sumber : Analisis Data Penelitian,

Keterangan : $* *=$ berbeda sangat signifikan

$*$ = berbeda signifikan

ns $=$ non signifikan/tidak signifikan

Tabel 4. Analisis Sidik Ragam Pengaruh Pemberian Atonik Terhadap Pertumbuhan

Tunas Stek Akar Peluntan di Persemaian.

\begin{tabular}{|l|c|c|c|c|c|c|}
\hline $\begin{array}{c}\text { Sumber } \\
\text { Keragaman }\end{array}$ & $\begin{array}{c}\text { Derajat } \\
\text { Bebas }\end{array}$ & $\begin{array}{c}\text { Jumlah } \\
\text { Kuadrat }\end{array}$ & $\begin{array}{c}\text { Kwadrat } \\
\text { Tengah }\end{array}$ & F. hitung & \multicolumn{2}{|c|}{ F tabel } \\
Perlakuan & 3 & 0,05 & 0,02 & $0,33^{\text {ns }}$ & 3,49 & 5,95 \\
Galat & 12 & 0,56 & 0,05 & & & \\
\hline Total & 15 & 0,61 & & & \\
\hline \multicolumn{7}{|c|}{$K K=4,95 \%$} \\
\hline
\end{tabular}

Sumber : Analisis Data Penelitian,

Keterangan :

ns : Non Signifikan / Tidak signifikan

Tabel 5. Analisis Sidik Ragam Pengaruh Pemberian Atonik Terhadap Pertumbuhan Tinggi Tunas Stek Akar Peluntan di Persemaian.

\begin{tabular}{|l|c|c|c|c|c|c|}
\hline $\begin{array}{c}\text { Sumber } \\
\text { Keragaman }\end{array}$ & $\begin{array}{c}\text { Derajat } \\
\text { Bebas }\end{array}$ & $\begin{array}{c}\text { Jumlah } \\
\text { Kuadrat }\end{array}$ & $\begin{array}{c}\text { Kwadrat } \\
\text { Tengah }\end{array}$ & F. hitung & \multicolumn{2}{|c|}{ F tabel } \\
\cline { 7 - 7 } Perlakuan & 3 & 51,69 & 17,23 & $5,63^{*}$ & 3,49 & 5,95 \\
Galat & 12 & 36,75 & 3,06 & & & \\
\hline Total & 15 & 38,94 & & & \\
\hline \multicolumn{7}{|c|}{ KK $=6,42 \%$} \\
\hline
\end{tabular}

Sumber : Analisis Data Penelitian,

Keterangan :

$$
\text { * : Berbeda Signifikan }
$$


Peluntan (Artocarpus sericicarpus)

Tabel 6. Uji Beda Nyata Terkecil Pengaruh Pemberian Atonik Terhadap Pertumbuhan Tinggi Tunas Stek Akar Peluntan Di Persemaian

\begin{tabular}{|l|c|l|l|l|l|}
\hline \multirow{2}{*}{ Perlakuan } & \multirow{2}{*}{ Rerata } & \multicolumn{4}{|c|}{ Aeda } \\
\cline { 3 - 6 } & & \multicolumn{1}{|c|}{ A0 } & \multicolumn{1}{|c|}{ A1 } & \multicolumn{1}{c|}{ A2 } \\
\hline A0 & 4,50 & - & & & \\
\hline A1 & 6,25 & $2,25^{*}$ & - & & \\
\hline A2 & 7,00 & $3,50^{*}$ & $1,25^{\text {ns }}$ & - & \\
\hline A3 & 9,50 & $5,00^{* *}$ & $3,25^{*}$ & $2,50^{\text {ns }}$ & - \\
\hline \multicolumn{5}{|c|}{ BNT 5\%:2,69 } & BNT $1 \%: 3,78$ \\
\hline
\end{tabular}

Sumber : Analisis Data Penelitian,

$$
\begin{aligned}
\text { Keterangan : } & * *=\text { berbeda sangat signifikan } \\
& *=\text { berbeda signifikan } \\
& \mathrm{ns}=\text { non signifikan/tidak signifikan }
\end{aligned}
$$

Tabel 7. Analisis Sidik Ragam Pengaruh Pemberian Atonik Terhadap Pertumbuhan Akar Stek Peluntan di Persemaian.

\begin{tabular}{|l|c|c|c|c|c|c|}
\hline \multicolumn{1}{|c|}{$\begin{array}{c}\text { Sumber } \\
\text { Keragaman }\end{array}$} & $\begin{array}{c}\text { Derajat } \\
\text { Bebas }\end{array}$ & $\begin{array}{c}\text { Jumlah } \\
\text { Kuadrat }\end{array}$ & $\begin{array}{c}\text { Kwadrat } \\
\text { Tengah }\end{array}$ & F. hitung & \multicolumn{2}{|c|}{ F tabel } \\
\cline { 1 - 1 } Perlakuan & 3 & 8,69 & 2,90 & $46,33^{* *}$ & 3,49 & 5,95 \\
Galat & 12 & 0,75 & 0,06 & & & \\
\hline Total & 15 & 9,44 & & & \\
\hline \multicolumn{6}{|c|}{$\mathrm{KK}=1,69 \%$} \\
\hline
\end{tabular}

Sumber : Analisis Data Penelitian,

Keterangan :

** : Berbeda Sangat Signifikan

Tabel 8. Uji Beda Nyata Terkecil Pengaruh Pemberian Atonik Terhadap Pertumbuhan Jumlah Akar Stek Akar Peluntan Di Persemaian

\begin{tabular}{|l|c|l|l|l|l|}
\hline \multirow{2}{*}{ Perlakuan } & \multirow{2}{*}{ Rerata } & \multicolumn{5}{|c|}{ Beda } \\
\cline { 3 - 6 } & & \multicolumn{1}{|c|}{ A0 } & \multicolumn{1}{|c|}{ A1 } & A2 \\
\hline A0 & 3,00 & - & & & \\
\hline A1 & 3,00 & $0,00^{\text {ns }}$ & - & & \\
\hline A2 & 4,00 & $1,00^{* *}$ & $1,00^{* *}$ & - & \\
\hline A3 & 4,75 & $1,75^{* *}$ & $1,75^{* *}$ & $0,75^{* *}$ & - \\
\hline \multicolumn{5}{|c|}{ BNT $5 \%: 0,38$} & BNT $1 \%: 0,53$ \\
\hline
\end{tabular}

Sumber : Analisis Data Penelitian,

$$
\text { Keterangan : } \begin{aligned}
* * & =\text { berbeda sangat signifikan } \\
\mathrm{ns} & =\text { non signifikan/tidak signifikan }
\end{aligned}
$$


Peluntan (Artocarpus sericicarpus)

Tabel 9. Analisis Sidik Ragam Pengaruh Pemberian Atonik Terhadap Pertumbuhan Panjang Akar Stek Peluntan di Persemaian.

\begin{tabular}{|l|c|c|c|c|c|c|}
\hline \multicolumn{1}{|c|}{$\begin{array}{c}\text { Sumber } \\
\text { Keragaman }\end{array}$} & $\begin{array}{c}\text { Derajat } \\
\text { Bebas }\end{array}$ & $\begin{array}{c}\text { Jumlah } \\
\text { Kuadrat }\end{array}$ & $\begin{array}{c}\text { Kwadrat } \\
\text { Tengah }\end{array}$ & F. hitung & \multicolumn{2}{|c|}{ F tabel } \\
\cline { 1 - 1 } & & & & & $\mathbf{5 \%}$ & $\mathbf{1 \%}$ \\
\hline Perlakuan & 3 & 3,17 & 1,06 & $10,34^{* *}$ & 3,49 & 5,95 \\
Galat & 12 & 1,23 & 0,10 & & & \\
\hline Total & 15 & 4,40 & & & \\
\hline \multicolumn{6}{|c|}{ KK $=3,71 \%$} \\
\hline
\end{tabular}

Sumber : Analisis Data Penelitian,

Keterangan :

** : Berbeda Sangat Signifikan

Tabel 10. Uji Beda Nyata Terkecil Pengaruh Pemberian Atonik Terhadap Pertumbuhan Panjang Akar Stek Akar Peluntan Di Persemaian

\begin{tabular}{|l|c|l|l|l|l|}
\hline \multirow{2}{*}{ Perlakuan } & \multirow{2}{*}{ Rerata } & \multicolumn{5}{|c|}{ Beda } \\
\cline { 3 - 6 } & & \multicolumn{1}{|c|}{ A0 } & \multicolumn{1}{|c|}{ A1 } & A2 & A3 \\
\hline A0 & 1,50 & - & & & \\
\hline A1 & 2,00 & $0,50^{*}$ & - & & \\
\hline A2 & 2,50 & $1,00^{* *}$ & $0,50^{*}$ & - & \\
\hline A3 & 2,63 & $1,13^{* *}$ & $0,63^{*}$ & $0,13^{\text {ns }}$ & - \\
\hline \multicolumn{5}{r}{ BNT 5\%:0,49 } & BNT $1 \%: 0,68$ \\
\hline
\end{tabular}

Sumber : Analisis Data Penelitian,

$$
\begin{aligned}
\text { Keterangan }: & * *=\text { berbeda sangat signifikan } \\
\mathrm{ns} & =\text { non signifikan/tidak signifikan }
\end{aligned}
$$

\section{Pembahasan}

Berdasarkan hasil penelitian sebagaimana yang disajikan pada tabel 1. diketahui bahwa stek akar Peluntan yang diberikan Atonik mampu hidup dengan persentase tumbuh sebesar $66,67 \%$ sedangkan yang tidak diberikan Atonik hanya mampu hidup sebesar 22,22\%. Bila dilihat dari angka tersebut, tentu sesungguhnya hasilnya belum memuaskan tetapi berdasarkan pengalaman empiris hasil ini sangat memuaskan, mengingat terdapat kesulitan dalam mencari akar Peluntan dan teknis pengambilan serta pemilihan stek yang akan dijadikan untuk bahan penelitian. Hasil penelitian yang menunjukkan bahwa terdapat persentase hidup sebesar 66,67\% memberikan indikasi bahwa secara umum 
Atoniuk yang diberikan dapat berfungsi sebagaimana mestinya. Hal ini sejalan dengan yang dinyatakan oleh Kusumo (1984:71) yang mengatakan bahwa Atonik bukan phytohormon, tetapi termasuk zat pengatur tumbuh, yang bermanfaat untuk memacu pertumbuhan supaya cepat besar dan menjadikan tanaman sehat.

Berdasarkan hasil penelitian terhadap pertumbuhan daun, tinggi tunas, jumlah akar utama dan panjang akar diketahui bahwa terdapat pengaruh yang signifikan bahkan terdapat juga pengaruh yang sangat ssignifikan. Terjadinya pengaruh yang signifikan ini memberikan indikasi bahwa Atonik yang diberikan telah bekerja dengan baik. Hal ini sesuai dengan pendapat Yasman dan Smith (1988), yang menyatakan bahwa pemberian hormon pada stek sangat memegang peranan penting. Konsentrasi yang terlalu rendah akan mengakibatkan pertumbuhan dan pertambahan tinggi menjadi lama, sedangkan konsentrasi yang terlalu tinggi akan berakibat racun bagi stek sehingga pertumbuhan dan perkembangannnya menjadi terhambat. Telah terjadinya pertumbuhan menggambarkan bahwa telah terjadi pembelahan dan perpanjangan sel pada daerah meristem. Hal yang serupa diungkapkan juga oleh Harjadi (1996:21), bahwa bertambah tingginya tanaman disebabkan oleh terjadinya pembelahan dan perpanjangan sel pada daerah meristem ujung tunas dan ujung akar.

Pertumbuhan dan perkembangan daun sangat dipengaruhi oleh akar tanaman tersebut. Apabila pertumbuhan akar terhambat maka akan menghambat pertumbuhan tanaman pada bagian atasnya. Setyati (1991), mengemukakan bahwa jaringan meristem pada ujung-ujung akar adalah sel - sel yang aktif terlibat dalam pembelahan dan pertumbuhan sel, sehingga penyerapan hara pada tanah akan menjadi lebih besar untuk proses metabolisme pada tanaman yang menghasilkan pertumbuhan termasuk pada daun.

Terbentuknya akar pada stek merupakan akibat adanya interaksi pergerakan ke bawah antara karbohidrat, auksin dan Co. Bila jumlah auksin tidak mencukupi dan belum dapat diserap oleh stek, maka 
pertumbuhan akar akan terhambat.

Terhambatnya pertumbuhan akar mengakibatkan terhambatnya npertumbuhan organ tanaman lainnya. Hal ini diungkapkan oleh Prawiranata (1991:36), Protein dan karbohidrat sebagai polimer hasil reaksi metabolik pada jaringan daun akan diubah dan dibentuk menjadi sel dan seterusnya menyusun jaringan dan sistem organ, seperti batang dan akar.

Pertumbuhan suatu stek juga sangat dipengaruhi oleh faktor yang ada didalam stek itu sendiri. Persediaan bahan makanan yang berupa zat arang dan protein harus mencukupi kebutuhan energi pembentuk jaringan. Menurut Nyekoi (1997:20), rasio C/N yang tinggi ternyata diperlukan untuk pembentukan akar yang cepat. Selanjutnya dikatakan bahwa stek yang diambil dari tanaman yang mengandung rasio $\mathrm{C} / \mathrm{N}$ yang tinggi akan memberikan pertumbuhan akar yang lebih banyak daripada bahan stek yang diambil dari tanaman yang mengandung rasio $\mathrm{C} / \mathrm{N}$ rendah.

Salah satu faktor lingkungan yang mempengaruhi pertumbuhan stek adalah suhu. Pada proses pembiakan tanaman melalui stek suhu yang dimaksud adalah suhu dalam ruangan dan suhu medium. Kondisi suhu harus tetap dipertahankan dan optimal, agar pertumbuhan stek dapat berlangsung sebagaimana mestinya. Menurut Nyakpa, dkk. (1988:19-23), suhu sangat berpengaruh terhadap proses fotosintesis, respirasi, transpirasi, absorpsi air dan hara. Fotosintesis, respirasi, transpirasi, absorpsi air dan hara meningkat jika suhu meningkat pula namun masih dalam kisaran suhu yang dibutuhkan begitu juga sebaliknya.

Berdasarkan hasil analisis statistik pada tabel 4.6, mengenai pertumbuhan tunas stek akar Peluntan diketahui bahwa pemberian Atonik tidak berpengaruh signifikan. Dengan kata lain seluruh perlakuan yang diberikankan, tidak tepat untuk merangsang pertumbuhan tunas stek akar Peluntan. Tidak adanya pengaruh yang signifikan terhadap tunas stek akar Peluntan, memberikan suatu penjelasan kemungkinan konsentrasi hormon belum mampu diserap oleh jaringan stek. Apabila hormon tersebut dapat terpenetrasi secara optimal kedalam 
jaringan stek, maka akan merangsang

perakaran stek sehingga tunas akan bertambah. Walaupun demikian, tidak siginifikannya pengaruh pemeberian Atonik terhadap pertumbuhan tunas stek akar Peluntan dapat dimungkin oleh wkatu yang terlalu singkat dalam merendam stek dan adanya unsur ketidakmmpuan adaptasi dari stek terhadap lingkungan tempat tumbuhnya yang baru. Hal ini sesuai dengan apa yang diungkapkan Omon (1997), bahwa waktu pemberian hormon sangat berpengaruh dalam menentukan konsentrasi dan pertumbuhan perakaran stek meranti. Belum maksimalnya pertumbuhan tunas stek akar Peluntan dapat terjadi karena zak aktif auksin yang terdapat dalam hormon belum terpentrasi secara maksimal ke dalam jaringan stek, sehingga pertumbuhan stek tersebut akan terlambat. Hal ini memperkuat dugaan bahwa apabila zat aktif auksin tersedia dan mencukupi untuk menstimulir pertumbuhan akar stek, maka akan berimplikasi kepada laju pertumbuhan. Pertumbuhan yang terjadi pada tanaman merupakan pencerminan dari jumlah dan ukuran protoplasma, serta peningkatan massa sel, sehingga menghasilkan pertambahan besar dari suatu dimensi tanaman sepanjang umurnya (Harianto, 1995:36).

\section{PENUTUP}

\section{Kesimpulan}

Berdasarkan hasil penelitian dan pengamatan, maka dapat disimpulkan sebagai berikut;

1. Pemberian Atonik memberikan pengaruh yang sangat signifikan terhadap pertumbuhan jumlah daun, tinggi tunas, jumlah akar dan panjang akar stek akar Peluntan di persemaian, tetapi tidak berpengaruh terhadap pertumbuhan jumlah tunas.

2. Perlakuan pemberian Atonik dengan dosis $0,5 \mathrm{ml}$ per litter air (A2) menunjukkan hasil yang terbaik untuk meningkatkan pertumbuhan jumlah daun, tinggi tunas, dan panjang akar stek akar Peluntan di persemaian, sedangkan untuk meningkatkan jumlah akar yang terbaik adalah perlakuan $0,75 \mathrm{ml}$ per litter air (A3). 
Peluntan (Artocarpus sericicarpus)

Saran

Perlu kajian yang lebih

mendalam untuk dapat memastikan pengaruh pemberian Atonik terhadap pertumbuhan stek akar Peluntan, yaitu dengan cara menambah lamanya waktu penelitian dan teknis pengambilan akar yang akan dijadikan bahan stek, sehingga didapatkan kesimpulan yang komprehensif.

\section{DAFTAR PUSTAKA}

Dwijosepoetro. 1985. Pengantar Fisiologi Tumbuhan. Jakarta: PT. Gramedia Pustaka Utama.

Hanafiah, KA. 2008. Rancangan Percobaan. Jakarta : PT. Raja Grafindo Persada.

Kusumo, K. 1984. Zat Pengatur Tumbuh Tanaman. Bogor : CV. Yasaguna .

Lingga, P. 1991. Petunjuk Penggunaan Pupuk. Penebar Swadaya.

Muljana, W. 1989. Bercocok Tanam Kopi. Semarang. Aneka Ilmu..

Najiyati, S dan Danarti. 1995. Kopi, Budidaya Penanganan
Pasca Panen. Jakarta: Penebar Swadaya.

Nasir, M. 1997. Pengaruh Cara Pemberian dan Dosis Atonik Pada Stump Bibit Kadaluarsa Sengon (Paraserianthes falcataria (L) Nielson) Terhadap Pertumbuhannya Di Lahan Hutan Trans. Skripsi Fakultas Pertanian Untan. Pontianak (Tidak di terbitkan).

Nyekoi, V. 1997. Pengaruh Ukuran Kelas Diameter Stek dan Dosis Pemupukan NPK Terhadap Pertumbuhan Stek Sungkai (Peronema canescens Jack) di Persemaian Sintang. Sintang: Skripsi. Fakultas Pertanian Universitas Kapuas Sintang (tidak dipublikasikan).

Poerwowidodo. 1990. Gatra Tanah dan Pembangunan Hutan Tanaman Industri (HTI) Indonesia. Jakarta: Rajawali Press.

Rinia. 1986. Pengaruh Dosis Atonik dan Lama Perendaman Terhadap Pertumbuhan Stek Sonokembang (Pterocarpus indicus Willd.) Di Persemaian. Skripsi Fakultas Pertanian Untan. Pontianak (Tidak diterbitkan). 
Pengaruh Pemberian Atonik Terhadap Pertumbuhan Stek Akar Peluntan (Artocarpus sericicarpus)

Sasli,I. 1994. Pengaruh Lama

Perendaman Benih dan

Konsentrasi Atonik

Terhadap Pertumbuhan

dan Produksi Tanaman

Wortel (Daucus carota L.

Var. Chantenay) Di Tanah

Gambut. Skripsi Fakultas

Pertanian Untan.

Pontianak (Tidak

diterbitkan).

Sarief, S. 1986. Kesuburan dan Pemupukan Tanah

Pertanian.

Bandung:

Pustaka Buana.
Sumiati, E., 1989. Pengaruh zat pengatur tumbuh terhadap hasil curd broccoli (Brassica oleraceae) kultivar Green Comet. Bul.Penel.Hort. Vol. XVIII. No.1, 1989.

Uhaedi Sutisna, Titi Kalima dan Purnadjaja, 1998. Pedoman Pengenalan Pohon Hutan Di Indonesia. PROSEA. Seri Manual. Bogor. 